\title{
Shall We Focus on the Eosinophil to Guide Treatment with Systemic Corticosteroids during Acute Exacerbations of Chronic Obstructive Pulmonary Disease (COPD)? CON
}

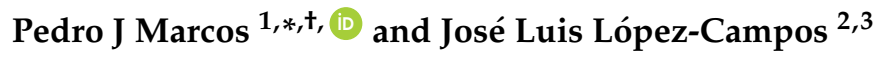 \\ 1 Dirección de Procesos Asistenciales, Servicio de Neumología, Instituto de Investigación Biomédica de A \\ Coruña (INIBIC), Complejo Hospitalario Universitario de A Coruña (CHUAC), Estructura Organizativa de \\ Xerencia de Xestión Integrada (EOXI) de A Coruña Sergas, Universidade da Coruña (UDC), \\ 15006 A Coruña, Spain \\ 2 Unidad Médico-Quirúrgica de Enfermedades Respiratorias, Instituto de Biomedicina de Sevilla (IBiS), \\ Hospital Universitario Virgen del Rocío/Universidad de Sevilla, 41013 Seville, Spain; lcampos@separ.es \\ 3 Centro de Investigación Biomédica en Red de Enfermedades Respiratorias (CIBERES), Instituto de Salud \\ Carlos III, 28029 Madrid, Spain \\ * Correspondence: pedro.jorge.marcos.rodriguez@sergas.es; Tel.: +34-981-178-000; Fax: +34-981-178-001 \\ † Current Address: Dirección Médica, Hospital de A Coruña, As Xubias de Arriba 84, 15006 A Coruña, Spain
}

Received: 18 April 2018; Accepted: 7 June 2018; Published: 8 June 2018

\begin{abstract}
The employment of systemic corticosteroids in the treatment of acute exacerbations of chronic obstructive pulmonary disease (COPD) has been shown to improve airway limitation, decrease treatment failure and risk of relapse, and may improve symptoms in addition to decreasing the length of hospital stay. Nowadays, all clinical guidelines recommend systemic corticosteroids to treat moderate or severe COPD exacerbations. However, their use is associated with potential side effects, mainly hyperglycemia. In the era of precision medicine, the possibility of employing blood eosinophil count has emerged as a potential way of optimizing therapy. Issues regarding the intra-individual variability of blood eosinophil count determination, a lack of clear data regarding the real prevalence of eosinophilic acute exacerbations, the fact that previously published studies have demonstrated the benefit of systemic corticosteroids irrespective of eosinophil levels, and especially the fact that there is only one well-designed study justifying this approach have led us to think that we are not ready to use eosinophil count to guide treatment with systemic corticosteroids during acute exacerbations of COPD.
\end{abstract}

Keywords: Chronic obstructive pulmonary disease (COPD); acute exacerbation; eosinophil; precision medicine; systemic corticosteroids

\section{Introduction}

Chronic obstructive pulmonary disease (COPD) is one of the leading causes of morbidity and mortality worldwide [1]. The course of COPD is characterized by episodes of increased symptoms known as exacerbations that, when severe enough, regularly require additional treatments. Exacerbations contribute to a long-term decline in lung function [2], reduced physical activity [3] and also have a significant and long-lasting effect on quality of life [4]. Patients with repeated exacerbations or with exacerbations that require hospitalization have been associated with an increased risk of morbidity and mortality $[2,5,6]$. Although those with less severe exacerbations are often managed as outpatients, COPD exacerbations may require hospitalization. Although the treatment of exacerbations 
is a significant contributor to the economic burden of COPD [7], COPD hospitalization is what most contributes to the global cost of the disease [8,9].

\section{Systemic Corticosteroids in COPD Exacerbation}

Chronic obstructive pulmonary disease exacerbation treatment aims to minimize the impact of the current exacerbation and prevent the development of subsequent events. Most COPD exacerbations can be safely managed in the outpatient setting. The main intervention consists of optimizing bronchodilation by increasing the dose and frequency of bronchodilators [10]. The other two key points are antibiotics and systemic corticosteroid treatment.

Although previously published data already suggested the potential benefit of systemic corticosteroids when treating patients with an acute exacerbation of COPD [11,12], it was the publication of a randomized trial by Niewoehner et al. [13] in 1999 which highlighted the importance of this treatment. They compared two regimens of systemic corticosteroids (SC, 2 or 8 weeks) versus a placebo and demonstrated that treatment with SC resulted in improved clinical outcomes (less treatment failure, shorter hospital stays and better lung function). It was also observed that the maximum benefit was obtained in the first two weeks of treatment. Based on these and new results [14], systemic corticosteroids were cemented as a cornerstone of therapy for these patients.

Some years later, Aaron et al. [15] studied the effectiveness of oral prednisone in reducing the risks of relapse after an outpatient exacerbation of COPD. They selected patients discharged from the emergency room who were randomized to receive 10 days of treatment of prednisone or placebo. They found a lower rate of relapse at 30 days ( $27 \%$ vs. $43 \%$; $p=0.05)$, longer time spent relapse-free at 30 days $(p=0.04)$ and a non-significant reduction in hospitalizations for COPD (11\% vs. $21 \% ; p=0.11)$. They also found that after 10 days of treatment, patients treated with systemic corticosteroids had greater improvements in lung function, less dyspnea and better quality of life based on the determinations of the chronic respiratory disease questionnaire (CRQ).

Since those cornerstone studies, new data has reinforced the effect of the treatment (sometimes being compared with steroid nebulized therapy $[14,16]$ ) and another studies even have questioned the effect in new hospital settings, like the intensive care unit (ICU) [17]. A Cochrane Review published in 2014 confirmed the benefit of systemic corticosteroids in preventing treatment failure versus placebo (odds ratio (OR) 0.49; 95\% confidence interval (CI), 0.35-0.67) [18] with high quality evidence resulting in a number of patients needed to treat to avoid one treatment failure of nine. There was moderate-quality evidence for a lower rate of relapse by one month for treatment with systemic corticosteroids (hazard ratio (HR) $0.78 ; 95 \%$ CI 0.63 to 0.97 ), better lung function, especially in the first three days (mean difference (MD) $140 \mathrm{~mL} ; 95 \%$ CI, 90 to 200), and shorter hospitalization for the inpatient (MD - -1.22 days; $95 \% \mathrm{CI},-2.26$ to -0.18 ). However, mortality up to 30 days was not reduced by treatment with systemic corticosteroids compared with the control in 12 studies $(n=1319$; OR 1.00; 95\% CI, 0.60 to 1.66), and the likelihood of adverse events, particularly hyperglycemia, increased with corticosteroid (CS) treatment (OR 2.33; 95\% CI, 1.59 to 3.43), with a number of patients needed to harm of 6 (95\% CI 4 to 10$)$.

The last robust and well-designed study regarding the impact of SC on COPD exacerbations was perhaps the "Reduce trial", published by Leuppi et al. in JAMA in 2013 [19]. In this study, patients arriving at the emergency department with acute exacerbations of COPD were randomized in order to detect whether five-day treatment with systemic glucocorticoids was non-inferior to 14-day treatment with regard to re-exacerbation within six months of follow-up. The study was positive, demonstrating non-inferior results with the short course, although with significantly reduced glucocorticoid exposure. A review of the most relevant studies regarding the efficacy of systemic corticosteroids can be seen in Table 1. 
Table 1. Most relevant studies regarding the efficacy of systemic corticosteroids (SC).

\begin{tabular}{|c|c|c|c|c|c|}
\hline Author & $n$ & Setting & Regimen & $\begin{array}{l}\text { Cumulated Dosage } \\
\text { (Prednisone, mg) }\end{array}$ & $\begin{array}{c}\text { SC } \\
\text { Total Days }\end{array}$ \\
\hline \multirow[t]{2}{*}{ Bullard [12] } & \multirow[t]{2}{*}{138} & \multirow{2}{*}{$\begin{array}{l}\text { Emergency } \\
\text { Department }\end{array}$} & $\begin{array}{l}\text { Arm 1: } 100 \mathrm{mg} \text { IV hydrocortisone } / 4 \mathrm{~h} \times 96 \mathrm{~h}+4 \\
\text { days oral prednisone } 40 \mathrm{mg}(5-8 \text { days })\end{array}$ & $640-760$ & 8 \\
\hline & & & Arm 2: Placebo & 0 & 0 \\
\hline \multirow{3}{*}{ Niewoehner [13] } & \multirow{3}{*}{147} & \multirow{3}{*}{ Inpatient } & $\begin{array}{l}\text { Arm } 1 \text { : Methylprednisolone } 125 \mathrm{mg} / 6 \mathrm{~h} \text { for } 72 \mathrm{~h} \text {, } \\
\text { followed by oral prednisone: } 60 \mathrm{mg} \text { on study days } \\
4 \text { through } 7,40 \mathrm{mg} \text { on days } 8 \text { through } 11,20 \mathrm{mg} \text { on } \\
\text { days } 12 \text { through } 43,10 \mathrm{mg} \text { on days } 44 \text { through } 50 \text {, } \\
\text { and } 5 \mathrm{mg} \text { on days } 51 \text { through } 57\end{array}$ & 2985 & 57 \\
\hline & & & $\begin{array}{l}\text { Arm 2: Methylprednisolone } 125 \mathrm{mg} / 6 \mathrm{~h} \text { for } 72 \mathrm{~h} \text {, } \\
\text { followed by oral prednisone: } 60 \mathrm{mg} \text { on days } \\
4 \text { through } 7,40 \mathrm{mg} \text { on days } 8 \text { through } 11 \text {, and } 20 \mathrm{mg} \\
\text { on days } 12 \text { through } 15 \text {, and placebo from study days } \\
16 \text { through } 57\end{array}$ & 2355 & 15 \\
\hline & & & Arm 3: Placebo & 0 & 0 \\
\hline \multirow{3}{*}{ Maltais [14] } & \multirow{3}{*}{199} & \multirow{3}{*}{ Inpatient } & Arm 1: Prednisone $30 \mathrm{mg} / 12 \mathrm{~h}$ & 210 & 7 \\
\hline & & & $\begin{array}{l}\text { Arm 2: Nebulized budesonide } 2 \mathrm{mg} / 6 \mathrm{~h} \text { for } 72 \mathrm{~h} \text {, } \\
\text { followed } 2000 \mathrm{mcg} / \mathrm{d} \text { of inhaled budesonide }\end{array}$ & 0 & 0 \\
\hline & & & Arm 3: Placebo & 0 & 0 \\
\hline \multirow{2}{*}{ Aaron [15] } & \multirow{2}{*}{147} & \multirow{2}{*}{ Outpatient } & Arm 1: $40 \mathrm{mg}$ oral prednisone/day & 400 & 10 \\
\hline & & & Arm 2: Placebo & 0 & 0 \\
\hline \multirow{3}{*}{ Gunen [16] } & 159 & Inpatient & $\begin{array}{l}\text { Arm 1: IV prednisolone } 40 \mathrm{mg} / \text { day for days } 1-15 \text { if } \\
\text { not discharged, oral methylprednisolone } 32 \mathrm{mg} / \text { day } \\
\text { for days } 11-15 \text { if discharged }\end{array}$ & 600 & 15 \\
\hline & & & $\begin{array}{l}\text { Arm 2: Nebulized budesonide (1500 mg quater in } \\
\text { die [q.i.d]) }\end{array}$ & 0 & 0 \\
\hline & & & Arm 3: no inhaled SC & 0 & 0 \\
\hline \multirow{2}{*}{ Leuppi [19] } & \multirow{2}{*}{314} & \multirow{2}{*}{$\begin{array}{l}\text { Inpatient/ } \\
\text { Outpatient }\end{array}$} & $\begin{array}{l}\text { Arm 1: Methylprednisolone } 40 \mathrm{mg} \text { on day } 1 \text {, } \\
40 \mathrm{mg} \text { / day days } 2 \text { to } 5 \text { + placebo days } 5-14 \text {. }\end{array}$ & 250 & 5 \\
\hline & & & $\begin{array}{l}\text { Arm 2: Methylprednisolone } 40 \mathrm{mg} \text { on day } 1, \\
40 \mathrm{mg} / \text { day days } 2 \text { to } 14\end{array}$ & 610 & 14 \\
\hline \multirow{2}{*}{ Abroug [17] } & \multirow{2}{*}{217} & \multirow{2}{*}{$\begin{array}{l}\text { Intensive care } \\
\text { unit (ICU) }\end{array}$} & Arm 1: Prednisone $1 \mathrm{mg} / \mathrm{kg}$ daily until discharge & Weight-based & Maximum 10 \\
\hline & & & Arm 2: Usual care & 0 & 0 \\
\hline
\end{tabular}

\section{Guideline Recommendations}

Nowadays, all clinical guidelines recommend systemic corticosteroids to treat moderate or severe COPD exacerbations. Recommendations regarding this issue have been changing in parallel to the development of new studies (Table 2). Systemic corticosteroids treatment was already recommended in the first Global Initiative for Chronic Obstructive Lung Disease (GOLD) workshop summary, published in 2001. Systemic corticosteroids were recommended as an addition to bronchodilator therapy, especially in the hospital management of acute exacerbations of COPD with level A evidence. There were doubts about the exact dosage, even when it was highlighted that high doses were associated with a significant risk of side effects. Finally, 30 to $40 \mathrm{mg}$ of oral prednisolone daily for 10 to 14 days was considered a "reasonable" compromise between efficacy and safety. This recommendation was based on level D evidence, pointing out that prolonged treatment does not result in greater efficacy and increases the risk of side effects.

During subsequent updates to the GOLD Guidelines, evidence regarding the dosage and duration was progressively changed from higher to lower doses and duration. As a result, in GOLD 2006, there was level C evidence for treatment with 30-40 mg of prednisone a day for seven to ten days, and in GOLD 2014, after the publication of the REDUCE (reduction in the use of corticosteroids in exacerbated COPD) [19] results, the recommendation changed to treatment for five days with a dosage of $40 \mathrm{mg}$ a day, with B level evidence. The 2014 update was the first time that GOLD suggested that nebulized corticosteroids (budesonide) alone may be an alternative to oral corticosteroids in the treatment of exacerbations. The last prominent GOLD recommendations regarding treatment with systemic corticosteroids were published in the 2017 edition, suggesting for the first time that systemic corticosteroids may be less efficacious in treating acute COPD exacerbations in patients with lower blood eosinophil levels. 
Table 2. Global Initiative for Chronic Obstructive Lung Disease (GOLD) recommendations regarding the treatment of acute exacerbations of COPD with SC.

\begin{tabular}{cccccc}
\hline Guideline & Drug & Dosage & Duration & $\begin{array}{c}\text { Level } \\
\text { of Recommendation }\end{array}$ & Note \\
\hline $\begin{array}{c}\text { GOLD } \\
\text { 2001 [20] }\end{array}$ & Prednisolone & $30-40 \mathrm{mg} / \mathrm{d}$ & $10-14$ days & D & $\begin{array}{c}\text { The exact dose that should be } \\
\text { given is not known, but high } \\
\text { doses are associated with } \\
\text { a significant risk of side effects } \\
\text { Prolonged treatment does not } \\
\text { result in a greater efficacy and } \\
\text { increases the risk of side effects }\end{array}$ \\
\hline $\begin{array}{c}\text { GOLD } \\
\text { 2006 [21] }\end{array}$ & Prednisolone & $\begin{array}{c}\text { 30-40 mg } \\
\text { prednisone/d }\end{array}$ & $7-10$ days & C & \\
\hline GOLD 2014 [1] & Prednisone & $40 \mathrm{mg} / \mathrm{d}$ & 5 days & B & $\begin{array}{l}\text { Nebulized budesonide alone may } \\
\text { be an alternative (although more } \\
\text { expensive) to oral corticosteroids } \\
\text { in the treatment of exacerbations }\end{array}$ \\
\hline $\begin{array}{c}\text { GOLD } \\
\text { 2017 [2] }\end{array}$ & Prednisone & $40 \mathrm{mg} / \mathrm{d}$ & 5 days & B & $\begin{array}{l}\text { Recent studies suggest that } \\
\text { glucocorticoids may be less } \\
\text { efficacious in treating acute } \\
\text { chronic obstructive pulmonary } \\
\text { disease (COPD) exacerbations in } \\
\text { patients with lower blood } \\
\text { eosinophil levels }\end{array}$ \\
\hline
\end{tabular}

\section{The Need for Phenotyping Exacerbations and the Potential of Eosinophils}

\subsection{Precision Medicine and COPD Exacerbations}

In the current era of precision medicine [23], COPD is increasingly recognized as being comprised of various phenotypes [24,25]. Phenotyping has identified options for targeted therapy, aiming to treat each patient according to his or her own characteristics [26]. Biomarkers that could predict treatment responses to anti-inflammatory drugs may be useful in optimizing the benefit versus risk ratio. There has been more interest regarding the possibility of phenotyping exacerbations since the 2011 publication by Bafadhel et al. [27], in which they showed that there were biologic COPD exacerbation clusters that are clinically indistinguishable and that biomarkers can be used to identify specific clinical phenotypes during exacerbations of COPD. In this study, authors could differentiate four distinct biologic exacerbation clusters: bacterial, viral, pauci-inflammatory and eosinophilic. Interestingly, the four different exacerbation types were the result of a mathematical model based on cluster and principal component analyses, and the crude data presented a clear overlap between the different types. Later that year, Gao et al. [28] also identified four exacerbation types according to cell distribution in sputum. After a lifetime of knowing but not noticing its potential, the eosinophil, specifically the blood count, has now taken center stage as the most clinically accessible biomarker to aid in the management of COPD.

\subsection{Eosinophilia Associated with COPD}

Ever since studies in the early nineties [29] suggested that exacerbations of chronic bronchitis were associated with marked airway eosinophilia, eosinophilic airway inflammation has been classically associated with asthma. Since airway eosinophilia is a reliable predictor of responsiveness to inhaled [30] and systemic corticosteroids treatment [31-33], its determination seems crucial for better management of these patients.

Sputum eosinophil count has been postulated as the best non-invasive way of detecting eosinophilic airway inflammation. However, its measurement has some intrinsic problems including moderate repeatability (intra-class coefficient of 0.49 at 12 weeks [34]) and primarily because it is time consuming, requires certain expertise, and because some patients do not provide adequate samples for analysis or do not provide point-of-care results [35]. As a result, blood eosinophil count appears to be a more practical approach. There has been significant interest in the role of blood eosinophil 
count in COPD, especially in predicting responses to inhaled corticosteroid therapy exacerbation rates, mostly from the studies showing that the higher the blood eosinophil count, the greater the benefit in reducing exacerbations [36,37].

\subsection{Blood Eosinophil-Guided Systemic Corticosteroids for Exacerbations of COPD, the Evidence to Date}

The predictive role of peripheral blood eosinophil counts as a surrogate biomarker of eosinophilic airway inflammation as a means to direct therapy during exacerbations was recently hypothesized [27]. Some data supporting this approach are that treatment responses to systemic corticosteroids are heterogeneous or do not impact tough clinical outcomes like mortality [18]. However, one of the most important concerns regarding this treatment it is that systemic corticosteroids treatment is associated with significant side effects as hyperglycemia, deep vein thrombosis, weight gain, osteoporosis, infections or neuropsychiatric disorders $[13,38,39])$. Even short oral corticosteroids courses have been associated with those side effects [39], and the effect is added when patients receive multiple steroids courses when suffering relapsing processes. All of these questions have made some authors to have focused on eosinophil as the cornerstone to guide COPD exacerbation treatment.

Reading carefully some studies regarding this issue, it seems that there is some evidence between patients who responded very well to systemic steroids and another who did not. For example, in the Aaron study [15] the absolute reduction in risk of relapse at 30 days was $16 \%$ with a $p$ value of 0.05 , but $95 \%$ confidence interval was between 0 and $32 \%$ or the absolute reduction in risk of hospitalization was $10 \%$, but again with a CI from -2 to 22 . So, can eosinophil be the biomarker that could help us to discriminate potential "responders"?

To date, only one study has shown that a biomarker-directed strategy (eosinophil count) can be safely used with good clinical results to guide prescription in COPD exacerbations [40]. The Bafadhel group [39] selected 164 patients, 109 of whom suffered an exacerbation and were randomized to a standard arm, where they received systemic corticosteroids for two weeks, or a biomarker-directed arm, where only patients with a blood eosinophil count of $\geq 2 \%$ received systemic corticosteroids while the others received placebo. The main outcome of the study was the non-inferiority in health status using the chronic respiratory questionnaire (CRQ), the equivalence of the proportion of treatment failure, and evidence of a reduction in CS exposure in the biomarker-directed study group. The results of the study were positive since CRQ improvement in the standard arm was similar to the biomarker-directed group (0.8 vs. 1.1, MD, 0.3 ; CI 95\% 0.0-0.06; $p=0.05$ ) and there were no differences in treatment failure $(13 \%$ vs. $5 \% ; 95 \% \mathrm{CI},-1$ to $16 ; p=0.07)$. There was also less exposure to systemic corticosteroids in the biomarker study group since $49 \%$ of the exacerbations did not receive systemic corticosteroids. Furthermore, it was found that in biomarker-negative exacerbations, those patients treated with systemic corticosteroids had $15 \%$ treatment failures compared with only $2 \%$ of those given placebo $(p=0.04)$.

The same group completed a further analysis [41] of randomized controlled studies comparing outcomes for patients with COPD exacerbations treated with prednisolone vs. non-prednisolone (placebo or equivalent). Of just six studies which fulfilled the criteria, only three of them had blood eosinophil count available at the onset of the exacerbation. After analyzing a total of 243 patients (95 patients with 107 exacerbations in the non-prednisolone group vs. 148 patients with 193 exacerbations in the prednisolone group), the study showed that patients presenting with an acute COPD exacerbation and a peripheral eosinophil blood count $\geq 2 \%$ had a significantly reduced treatment failure rate compared with the placebo group $(20 \%$ vs. $45 \% ; p<0.001)$.

\section{Are We Ready to Use Eosinophil Count to Guide Treatment with Systemic Corticosteroids During Acute Exacerbations of COPD? Not Yet}

There are some concerns regarding this question which should better be addressed before taking the step to treat patients in this new way. 


\subsection{Can Eosinophils be Trusted in Clinical Practice}

Moving on from the role sputum eosinophilia plays in clinical practice due to the problems explained above, there are concerns regarding the use of blood count eosinophilia in the clinical setting. Although it has been proven that there is good agreement between two blood eosinophil count measurements of over a median of 28 days ( $\mathrm{Ri}$, intra-class correlation coefficient $=0.8 ; 95 \%$ CI: $0.66-0.88 ; p<0.001$ ) or even over 1 year ( $\mathrm{Ri}, 0.64)$, these results represent an average of group results, and when managing individual patients and making decisions based on these results in clinical practice, the benefit may not be so obvious. There is significant intra-subject variability with the peripheral blood eosinophil test, and there are a number of factors that contribute to within-subject variability of blood eosinophil measurements, particularly those that lower the count and could lead to a false negative test [42]. Blood eosinophil counts have been described to vary with exercise, food or medications. There is also a significant diurnal variability of blood eosinophil count with peak levels recorded around midnight and lowest levels at midday and a within-subject biological variation in hourly eosinophil count of $20.9 \%$ has been described. Furthermore, although a good correlation between sputum and eosinophilia has recently been suggested, a recent major study based on the SPIROMICS cohort analysis found that blood eosinophils alone showed a significant but weak association with sputum eosinophil counts (receiver operating characteristic area under the curve of $0 \cdot 64, p<0.0001$ ) with a high false-discovery rate of $72 \%$. It has also been shown to not be a reliable biomarker for COPD severity, exacerbations or sputum eosinophils [43]. This data needs to be taken into account, since SPIROMICS is the largest prospective study to date to have investigated sputum and blood eosinophil counts and their association with clinical outcomes in a population at low risk of exacerbation [44]. Furthermore, there are subtypes of eosinophils that are indistinguishable with the usual hematological stains.

\subsection{How Many Patients Could Benefit from This Approach}

It is not clear what the optimal cut-off point is for blood eosinophils. In the Bafadhel study [27], a cut-off at $2 \%$ of blood eosinophil counts distinguishes between eosinophilic and non-eosinophilic COPD exacerbation with a $90 \%$ sensitivity. Thus, most studies have adopted this cut-off value. However, even if we take an eosinophil level of $2 \%$ as valid, there are not many studies that have investigated the prevalence of eosinophilia on top of an exacerbation. Most of the data (Table 3) came from retrospective studies, with a wide range of prevalence (9.6 to $40 \%$ ), and different cut-off points $(>2 \%, \geq 2 \%)$, absolute number of eosinophils, etc. [45-49]. The fact that the eosinophil count is known to fall by $>50 \%$ within the first four hours following systemic corticosteroids administration [50] and the retrospective nature of these studies highlighted a potential confounding bias arising from the real prevalence of systemic corticosteroids administration in severe eosinophilic COPD. Ultimately, there really isn't any data regarding the real role of the eosinophil on community exacerbations of COPD.

Table 3. Prevalence of eosinophilia in severe COPD exacerbations.

\begin{tabular}{|c|c|c|c|c|c|}
\hline & \multirow[b]{2}{*}{$\mathbf{n}$} & \multirow[b]{2}{*}{ Design } & \multicolumn{3}{|c|}{ Cut-off } \\
\hline & & & $\begin{array}{c}\text { Eosinophils } \\
>2 \%\end{array}$ & $\begin{array}{l}\text { Eosinophils } \\
\geq 2 \%\end{array}$ & $\begin{array}{l}\text { Eosinophils } \\
>300 \text { cells } / \mu \mathrm{L}\end{array}$ \\
\hline Hasegawa [45] & 3084 & Retrospective & & $40 \%$ & $17 \%$ \\
\hline Salturk [46] & 647 & Retrospective & $9.6 \%$ & & \\
\hline Duman [44] & 1704 & Retrospective & $20.6 \%$ & & \\
\hline Serafino-Agrusa [47] & 132 & Retrospective & & $15.1 \%$ & \\
\hline Couillard [48] * & 167 & Retrospective & & $32.9 \%$ & \\
\hline
\end{tabular}

* Cut-off point defined as: Eosinophils $\geq 2 \%$ and/or $\geq 200$ cells $/ \mu \mathrm{L}$ of the total leukocyte count. 


\subsection{Did Previous Studies Supporting the Use of Systemic Corticosteroids Measure the Eosinophil Count}

There is no doubt regarding the beneficial results of employing systemic corticosteroids to treat COPD exacerbations [18]. Most of the papers that justified their use did not show results regarding the eosinophil count, at least the most robust ones $[13,15,19,51]$. We do not know if it is because they did not collect the data or they simply did not show it. The point is that those studies demonstrated a positive outcome for systemic corticosteroids independent of eosinophil count levels and, based on their randomized designs, it is expected that eosinophilic and non-eosinophilic patients had been properly distributed between the study arms.

Interestingly, for treatment selection we would like to have a highly predictive negative value to discard candidates or, the other way around, to have a highly positive predictive value to select candidates for therapy. $2 \%$ is a low limit so probably the philosophy behind is that of selecting non-responders. In any case, when a higher limit is defined we will then always have a level of uncertainty with middle values, which allows this biomarker to be used in a selection of patients.

\subsection{Any Light at the End of the Tunnel}

The 2017 GOLD guidelines recommendation states that, "Recent studies suggest that glucocorticoids may be less efficacious in treating acute COPD exacerbations in patients with lower levels of blood eosinophils." To date, it is only based on the 109 patients and 166 exacerbation events in the Bafadhel study [40] we mentioned before, and it appears that in order to make such a strong recommendation leading to a change in the clinical practice in so many patients, further studies and evidence in more patients would be necessary. Although it is a very well-designed study, it does have some limitations (in addition to sample size) that have to be pointed out which could question the recommendation. Firstly, only 10 patients in that cohort suffered from a severe exacerbation, so the application of the eosinophil count to guide treatment with systemic corticosteroids during acute exacerbations of COPD that require hospitalization is not clear and would need more data to be clearly recommended. Secondly, all patients in the study received antibiotics. Although this methodology could be justified in order to replicate the methods employed in the systemic corticosteroids studies where most of the patients received also antibiotics, we would like to highlight that in real clinical setting antibiotic decisions are based on Anthonisen criteria in moderate exacerbations. Thirdly, all of the patients that participated in the study had to have a prior history of exacerbations. We do not know if this approach could be applied to patients with infrequent exacerbations since we do not know if that characteristic could be related to a different therapeutic response. Finally, there is a methodological concern due to the fact that this study applied randomization by minimization which, while a good approach for randomized patients within a small sample size, also has some limitations [52]. Compared with a simple randomization where the allocation of future patients to a trial cannot be predicted, minimization has the disadvantage that, in certain cases, the next allocation can be predicted with certainty with knowledge of the characteristics of earlier patients. There is therefore a potential for selection bias, which can affect the validity of a trial's results. Even knowing which allocation is more likely to occur next can result in selection bias.

Although no new studies have been published, there is an ongoing, multi-center, randomized, controlled, open-label trial [53] which will help to better address this question. Authors will randomize over 300 patients to test if standard care compared to eosinophil-guided systemic corticosteroids -sparing therapy is non-inferior regarding length of hospital stay (primary outcome). This is expected to answer the uncertainties of Bafadhel's study as, because patients of the study are admitted to the hospital, patients with and without history of previous exacerbations were included and it has a bigger sample size. 


\section{Is it Realistic for These Recommendations to be Implemented in Clinical Practice in the Short Term}

Although the GOLD general recommendation of employing short-term systemic corticosteroids regimens to treat COPD acute exacerbations were first recommended in 2006, when a regimen of 30-40 mg of prednisone was recommended for 7-10 days, and this recommendation was re-adapted in GOLD 2014 based on the REDUCE Trial [19] to $40 \mathrm{mg}$ a day for five days, the application in clinical practice is lacking $[37,54-58]$. Our group recently published a study where we detected that most of the patients admitted to the hospital with a COPD exacerbation did not receive systemic corticosteroids therapy according to guidelines, this patients received more dosages and more days than recommended, and this was associated with a prolonged hospital stay [54]. As a result, it is a long road of unknown duration from the time Guidelines recommend a change until it is generally accepted and employed.

Another question that has to be taken into account is that, by definition, a blood sample is required. This does not pose any problem in the patients who are admitted to the hospital or who consult an emergency service. However, this can be a problem in outpatient clinics, and specially in primary care where there is usually a large volume of patients and urgent analysis cannot always be done, showing a probably lack of potential application as a practical test of this approach in this setting. Even more, the new approach suggested by the study by Sivapalan et al. [53], where the discontinuation of systemic corticosteroids would be based on a daily blood eosinophil test analysis, argues that this approach could go against clinical practice in the hospital setting.

Although nowadays most COPD patients who suffer from severe COPD exacerbations are elderly people with significant comorbidity and are likely have decreased immunity [59], systemic steroids have been associated with positive outcomes.

\section{Conclusions}

Systemic corticosteroids have been shown to improve clinical outcomes in the treatment of COPD exacerbations. However, their use is associated with potential side effects. In the era of precision medicine, the possibility of employing blood eosinophil count has appeared as a potential way to optimize therapy. Nevertheless, there are few clinical trials focused on properly addressing the question and more clinical data is needed.

Conflicts of Interest: The authors declare no conflict of interest.

\section{References}

1. Global Initiative for Chronic Obstructive Lung Disease, Executive and Science Commitees. Global Strategy for the Diagnosis, Management, and Prevention of Chronic Obstructive Pulmonary Disease; Global Initiative for Chronic Obstructive Lung Disease, Executive and Science Commitees, 2014.

2. Donaldson, G.C.; Seemungal, T.A.R.; Bhowmik, A.; Wedzicha, J.A. Relationship between exacerbation frequency and lung function decline in chronic obstructive pulmonary disease. Thorax 2002, 57, 847-852. [CrossRef] [PubMed]

3. Donaldson, G.C.; Wilkinson, T.M.A.; Hurst, J.R.; Perera, W.R.; Wedzicha, J.A. Exacerbations and time spent outdoors in chronic obstructive pulmonary disease. Am. J. Respir. Crit. Care Med. 2005, 171, 446-452. [CrossRef] [PubMed]

4. Wilkinson, T.M.A.; Donaldson, G.C.; Hurst, J.R.; Seemungal, T.A.R.; Wedzicha, J.A. Early therapy improves outcomes of exacerbations of chronic obstructive pulmonary disease. Am. J. Respir. Crit. Care Med. 2004, 169, 1298-1303. [PubMed]

5. Soler-Cataluna, J.J.; Martínez-García, M.Á.; Román Sánchez, P.; Salcedo, E.; Navarro, M.; Ochando, R. Severe acute exacerbations and mortality in patients with chronic obstructive pulmonary disease. Thorax 2005, 60, 925-931. [CrossRef] [PubMed] 
6. Schmidt, S.A.J.; Johansen, M.B.; Olsen, M.; Xu, X.; Parker, J.M.; Molfino, N.A.; Lash, T.L.; Sørensen, H.T.; Christiansen, C.F. The impact of exacerbation frequency on mortality following acute exacerbations of COPD: A registry-based cohort study. BMJ Open 2014, 4, e006720. [CrossRef] [PubMed]

7. Simoens, S. The economic burden of COPD exacerbations. COPD 2010, 7, 159-161. [CrossRef] [PubMed]

8. Wang, Q.; Bourbeau, J. Outcomes and health-related quality of life following hospitalization for an acute exacerbation of COPD. Respirology 2005, 10, 334-340. [CrossRef] [PubMed]

9. Oostenbrink, J.B.; Rutten-van Mölken, M.P.M.H. Resource use and risk factors in high-cost exacerbations of COPD. Respir. Med. 2004, 98, 883-891. [CrossRef] [PubMed]

10. Wedzicha, J.A.; Miravitlles, M.; Calverley, P.A.; Albert, R.K.; Anzueto, A.; Criner, G.J.; Papi, A.; Rabe, K.F.; Rigau, D.; Sliwinski, P.; et al. Management of COPD exacerbations: A European Respiratory Society / American Thoracic Society guideline. Eur. Respir. J. 2017, 49, 1600791. [CrossRef] [PubMed]

11. Albert, R.K.; Martin, T.R.; Lewis, S.W. Controlled clinical trial of methylprednisolone in patients with chronic bronchitis and acute respiratory insufficiency. Ann. Intern. Med. 1980, 92, 753-758. [CrossRef] [PubMed]

12. Bullard, M.J.; Liaw, S.J.; Tsai, Y.H.; Min, H.P. Early corticosteroid use in acute exacerbations of chronic airflow obstruction. Am. J. Emerg. Med. 1996, 14, 139-143. [CrossRef]

13. Niewoehner, D.E.; Erbland, M.L.; Deupree, R.H.; Collins, D.; Gross, N.J.; Light, R.W.; Anderson, P.; Morgan, N.A. Effect of systemic glucocorticoids on exacerbations of chronic obstructive pulmonary disease. N. Engl. J. Med. 1999, 340, 1941-1947. [CrossRef] [PubMed]

14. Maltais, F.; Ostinelli, J.; Bourbeau, J.; Tonnel, A.B.; Jacquemet, N.; Haddon, J.; Rouleau, M.; Boukhana, M.; Martinot, J.B.; Duroux, P. Comparison of nebulized budesonide and oral prednisolone with placebo in the treatment of acute exacerbations of chronic obstructive pulmonary disease: A randomized controlled trial. Am. J. Respir. Crit. Care Med. 2002, 165, 698-703. [CrossRef] [PubMed]

15. Aaron, S.D.; Vandemheen, K.L.; Hebert, P.; Dales, R.; Stiell, I.G.; Ahuja, J.; Dickinson, G.; Brison, R.; Rowe, B.H.; Dreyer, J.; et al. Outpatient oral prednisone after emergency treatment of chronic obstructive pulmonary disease. N. Engl. J. Med. 2003, 348, 2618-2625. [CrossRef] [PubMed]

16. Gunen, H.; Hacievliyagil, S.S.; Yetkin, O.; Gulbas, G.; Mutlu, L.C.; In, E. The role of nebulised budesonide in the treatment of exacerbations of COPD. Eur. Respir. J. 2007, 29, 660-667. [CrossRef] [PubMed]

17. Abroug, F.; Ouanes-Besbes, L.; Fkih-Hassen, M.; Ouanes, I.; Ayed, S.; Dachraoui, F.; Brochard, L.; Elatrous, S. Prednisone in COPD exacerbation requiring ventilatory support: An open-label randomised evaluation. Eur. Respir. J. 2014, 43, 717-724. [CrossRef] [PubMed]

18. Walters, J.A.E.; Tan, D.J.; White, C.J.; Gibson, P.G.; Wood-Baker, R.; Walters, E.H. Systemic corticosteroids for acute exacerbations of chronic obstructive pulmonary disease. Cochrane Database Syst. Rev. 2014, 348, CD001288. [CrossRef] [PubMed]

19. Leuppi, J.D.; Schuetz, P.; Bingisser, R.; Bodmer, M.; Briel, M.; Drescher, T.; Duerring, U.; Henzen, C.; Leibbrandt, Y.; Maier, S.; et al. Short-term vs. Conventional Glucocorticoid Therapy in Acute Exacerbations of Chronic Obstructive Pulmonary Disease. JAMA 2013, 309, 2223-2229. [CrossRef] [PubMed]

20. Pauwels, R.A.; Buist, A.S.; Calverley, P.M.; Jenkins, C.R.; Hurd, S.S.; GOLD Scientific Committee. Global Strategy for the Diagnosis, Management, and Prevention of Chronic Obstructive Pulmonary Disease; NHLBI/WHO Global Initiative for Chronic Obstructive Lung Disease (GOLD) Workshop Summary; American Thoracic Society: New York, NY, USA, 2001; Volume 163, pp. 1256-1276.

21. Global Initiative for Chronic Obstructive Lung Disease, Executive and Science Commitees. Global Strategy for the Diagnosis, Management, and Prevention of Chronic Obstructive Pulmonary Disease; Global Initiative for Chronic Obstructive Lung Disease, Executive and Science Commitees, 2006.

22. Global Initiative for Chronic Obstructive Lung Disease, Executive and Science Commitees. Global Strategy for the Diagnosis, Management, and Prevention of Chronic Obstructive Pulmonary Disease; Global Initiative for Chronic Obstructive Lung Disease, Executive and Science Commitees, 2017.

23. Hurst, J.R. Precision Medicine in Chronic Obstructive Pulmonary Disease. Am. J. Respir. Crit. Care Med. 2016, 193, 593-594. [CrossRef] [PubMed]

24. Miravitlles, M.; Soler-Cataluña, J.J.; Calle, M.; Molina, J.; Almagro, P.; Quintano, J.A.; Trigueros, J.A.; Cosío, B.G.; Casanova, C.; Antonio Riesco, J.; et al. Spanish Guidelines for Management of Chronic Obstructive Pulmonary Disease (GesEPOC). Arch. Bronconeumol. 2012, 48 (Suppl. 1), 2-58.

25. Hurst, J.R.; Vestbo, J.; Anzueto, A.; Locantore, N.; Müllerova, H.; Tal-Singer, R.; Miller, B.; Lomas, D.A.; Agustí, A.; Macnee, W.; et al. Evaluation of COPD Longitudinally to Identify Predictive Surrogate Endpoints (ECLIPSE) 
Investigators Susceptibility to exacerbation in chronic obstructive pulmonary disease. N. Engl. J. Med. 2010, 363, 1128-1138. [CrossRef] [PubMed]

26. Woodruff, P.G.; Agustí, A.; Roche, N.; Singh, D.; Martinez, F.J. Current concepts in targeting chronic obstructive pulmonary disease pharmacotherapy: Making progress towards personalised management. Lancet 2015, 385, 1789-1798. [CrossRef]

27. Bafadhel, M.; McKenna, S.; Terry, S.; Mistry, V.; Reid, C.; Haldar, P.; McCormick, M.; Haldar, K.; Kebadze, T.; Duvoix, A.; et al. Acute Exacerbations of Chronic Obstructive Pulmonary Disease. Am. J. Respir. Crit. Care Med. 2011, 184, 662-671. [CrossRef] [PubMed]

28. Gao, P.; Zhang, J.; He, X.; Hao, Y.; Wang, K.; Gibson, P.G. Sputum inflammatory cell-based classification of patients with acute exacerbation of chronic obstructive pulmonary disease. PLOS ONE 2013, 8, e57678. [CrossRef] [PubMed]

29. Saetta, M.; Di Stefano, A.; Maestrelli, P.; Turato, G.; Ruggieri, M.P.; Roggeri, A.; Calcagni, P.; Mapp, C.E.; Ciaccia, A.; Fabbri, L.M. Airway eosinophilia in chronic bronchitis during exacerbations. Am. J. Respir. Crit. Care Med. 1994, 150, 1646-1652. [CrossRef] [PubMed]

30. Brightling, C.E.; McKenna, S.; Hargadon, B.; Birring, S.; Green, R.; Siva, R.; Berry, M.; Parker, D.; Monteiro, W.; Pavord, I.D.; et al. Sputum eosinophilia and the short term response to inhaled mometasone in chronic obstructive pulmonary disease. Thorax 2005, 60, 193-198. [CrossRef] [PubMed]

31. Pizzichini, E.; Pizzichini, M.M.; Gibson, P.; Parameswaran, K.; Gleich, G.J.; Berman, L.; Dolovich, J.; Hargreave, F.E. Sputum eosinophilia predicts benefit from prednisone in smokers with chronic obstructive bronchitis. Am. J. Respir. Crit. Care Med. 1998, 158, 1511-1517. [CrossRef] [PubMed]

32. Siva, R.; Green, R.H.; Brightling, C.E.; Shelley, M.; Hargadon, B.; McKenna, S.; Monteiro, W.; Berry, M.; Parker, D.; Wardlaw, A.J.; et al. Eosinophilic airway inflammation and exacerbations of COPD: A randomised controlled trial. Eur. Respir. J. 2007, 29, 906-913. [PubMed]

33. Bafadhel, M.; Saha, S.; Siva, R.; McCormick, M.; Monteiro, W.; Rugman, P.; Dodson, P.; Pavord, I.D.; Newbold, P.; Brightling, C.E. Sputum IL-5 concentration is associated with a sputum eosinophilia and attenuated by corticosteroid therapy in COPD. Respiration 2009, 78, 256-262. [CrossRef] [PubMed]

34. Beeh, K.M.; Beier, J.; Kornmann, O.; Mander, A.; Buhl, R. Long-term repeatability of induced sputum cells and inflammatory markers in stable, moderately severe COPD. Chest 2003, 123, 778-783. [CrossRef] [PubMed]

35. Negewo, N.A.; McDonald, V.M.; Baines, K.J.; Wark, P.A.; Simpson, J.L.; Jones, P.W.; Gibson, P.G. Peripheral blood eosinophils: A surrogate marker for airway eosinophilia in stable COPD. COPD 2016, 11, 1495-1504. [CrossRef] [PubMed]

36. Pascoe, S.; Locantore, N.; Dransfield, M.T.; Barnes, N.C.; Pavord, I.D. Blood eosinophil counts, exacerbations, and response to the addition of inhaled fluticasone furoate to vilanterol in patients with chronic obstructive pulmonary disease: A secondary analysis of data from two parallel randomised controlled trials. Lancet Respir. Med. 2015, 3, 435-442. [CrossRef]

37. Pavord, I.D.; Lettis, S.; Locantore, N.; Pascoe, S.; Jones, P.W.; Wedzicha, J.A.; Barnes, N.C. Blood eosinophils and inhaled corticosteroid/long-acting $\beta$-2 agonist efficacy in COPD. Thorax 2016, 71, 118-125. [CrossRef] [PubMed]

38. Baker, J.M.; Pace, H.A.; Ladesich, J.B.; Simon, S.D. Evaluation of the Impact of Corticosteroid Dose on the Incidence of Hyperglycemia in Hospitalized Patients with an Acute Exacerbation of Chronic Obstructive Pulmonary Disease. Hosp. Pharm. 2016, 51, 296-304. [CrossRef] [PubMed]

39. Bénard-Laribière, A.; Pariente, A.; Pambrun, E.; Bégaud, B.; Fardet, L.; Noize, P. Prevalence and prescription patterns of oral glucocorticoids in adults: A retrospective cross-sectional and cohort analysis in France. BMJ Open 2017, 7, e015905. [CrossRef] [PubMed]

40. Bafadhel, M.; McKenna, S.; Terry, S.; Mistry, V.; Pancholi, M.; Venge, P.; Lomas, D.A.; Barer, M.R.; Johnston, S.L.; Pavord, I.D.; et al. Blood Eosinophils to Direct Corticosteroid Treatment of Exacerbations of Chronic Obstructive Pulmonary Disease. Am. J. Respir. Crit. Care Med. 2012, 186, 48-55. [CrossRef] [PubMed]

41. Bafadhel, M.; Davies, L.; Calverley, P.M.A.; Aaron, S.D.; Brightling, C.E.; Pavord, I.D. Blood eosinophil guided prednisolone therapy for exacerbations of COPD: A further analysis. Eur. Respir. J. 2014, 44, 789-791. [CrossRef] [PubMed]

42. Gibson, P.G. Variability of blood eosinophils as a biomarker in asthma and COPD. Respirology 2018, 23, 12-13. [CrossRef] [PubMed] 
43. Hastie, A.T.; Martinez, F.J.; Curtis, J.L.; Doerschuk, C.M.; Hansel, N.N.; Christenson, S.; Putcha, N.; Ortega, V.E.; Li, X.; Barr, R.G.; et al. SPIROMICS investigators. Association of sputum and blood eosinophil concentrations with clinical measures of COPD severity: An analysis of the SPIROMICS cohort. Lancet Respir. 2017, 5, 956-967. [CrossRef]

44. Bafadhel, M. Eosinophils in COPD: Are we nearly there yet? Lancet Respir. 2017, 5, 913-914. [CrossRef]

45. Duman, D.; Aksoy, E.; Agca, M.C.; Kocak, N.D.; Ozmen, I.; Akturk, U.A.; Gungor, S.; Tepetam, F.M.; Eroglu, S.A.; Oztas, S.; et al. The utility of inflammatory markers to predict readmissions and mortality in COPD cases with or without eosinophilia. COPD 2015, 10, 2469-2478. [CrossRef] [PubMed]

46. Hasegawa, K.; Camargo, C.A., Jr. Prevalence of blood eosinophilia in hospitalized patients with acute exacerbation of COPD. Respirology 2015, 21, 761-764. [CrossRef] [PubMed]

47. Saltürk, C.; Karakurt, Z.; Adiguzel, N.; Kargin, F.; Sari, R.; Celik, M.E.; Takir, H.B.; Tuncay, E.; Sogukpinar, O.; Ciftaslan, N.; et al. Does eosinophilic COPD exacerbation have a better patient outcome than non-eosinophilic in the intensive care unit? COPD 2015, 10, 1837-1846. [CrossRef] [PubMed]

48. Serafino-Agrusa, L.; Scichilone, N.; Spatafora, M.; Battaglia, S. Blood eosinophils and treatment response in hospitalized exacerbations of chronic obstructive pulmonary disease: A case-control study. Pulm. Pharmacol. Ther. 2016, 37, 89-94. [CrossRef] [PubMed]

49. Couillard, S.; Larivée, P.; Courteau, J.; Vanasse, A. Eosinophils in COPD Exacerbations Are Associated With Increased Readmissions. Chest 2017, 151, 366-373. [CrossRef] [PubMed]

50. Thorn, G.W.; Renold, A.E.; Wilson, D.L.; Frawley, T.F.; Jenkins, D.; García-Reyes, J.; Forsham, P.H. Clinical studies on the activity of orally administered cortisone. N. Engl. J. Med. 1951, 245, 549-555. [CrossRef] [PubMed]

51. de Jong, Y.P.; Uil, S.M.; Grotjohan, H.P.; Postma, D.S.; Kerstjens, H.A.; van den Berg, J.W. Oral or IV Prednisolone in the Treatment of COPD Exacerbations. Chest 2018, 132, 1741-1747. [CrossRef] [PubMed]

52. Scott, N.W.; McPherson, G.C.; Ramsay, C.R.; Campbell, M.K. The method of minimization for allocation to clinical trials. a review. Control Clin. Trials 2002, 23, 662-674. [CrossRef]

53. Sivapalan, P.; Moberg, M.; Eklöf, J.; Janner, J.; Vestbo, J.; Laub, R.R.; Browatzki, A.; Armbruster, K.; Wilcke, J.T.; Seersholm, N.; et al. A multi-center randomized, controlled, open-label trial evaluating the effects of eosinophil-guided corticosteroid-sparing therapy in hospitalised patients with COPD exacerbations-The CORTICO steroid reduction in COPD (CORTICO-COP) study protocol. BMC Pulm. Med. 2017, 17, 114. [CrossRef] [PubMed]

54. Marcos, P.J.; Nieto-Codesido, I.; de Jorge Dominguez-Pazos, S.; Huerta, A.; Márquez, E.; Maiso, A.; Verdeal, R.; Otero-Gonzalez, I.; Blanco-Aparicio, M.; Montero-Martínez, C. Treatment With Systemic Steroids in Severe Chronic Obstructive Pulmonary Disease Exacerbations: Use of Short Regimens in Routine Clinical Practice and Their Impact on Hospital Stay. Arch. Bronconeumol. 2017, 53, 611-615. [CrossRef] [PubMed]

55. Wang, P.H.; Cheng, S.L.; Wang, H.C.; Chang, H.T.; Hsu, Y.L.; Chen, Y.S.; Chang, C.Y. Systemic steroids in acute exacerbation of COPD-From guidelines to bedside. Int. J. Clin. Pharmacol. Ther. 2012, 49, 705-708. [CrossRef]

56. Miravitlles, M. Medicina basada en la no-evidencia: El ejemplo del uso de los corticosteroides sistémicos en la agudización de la EPOC. Revista Clínica Española 2017, 217, 520-521. [CrossRef] [PubMed]

57. Rueda-Camino, J.A.; Bernal-Bello, D.; Canora-Lebrato, J.; Velázquez-Ríos, L.; de Viedma-García, V.G.; Guerrero-Santillán, M.; Duarte-Millán, M.A.; Cristóbal-Bilbao, R.; Zapatero-Gaviria, A. Dosis altas de corticoides sistémicos en pacientes ingresados por exacerbación de enfermedad pulmonar obstructiva crónica. Un estudio de cohortes. Revista Clínica Española 2017, 217, 504-509. [CrossRef] [PubMed]

58. Marcos, P.J.; Huerta, A.; Márquez-Martín, E. 2014 GesEPOC and Systemic Steroids in chronic obstructive pulmonary disease (COPD) Exacerbation: An Update. Arch. Bronconeumol. 2015, 51, 360. [CrossRef] [PubMed]

59. Hanania, N.A.; Sharma, G.; Sharafkhaneh, A. COPD in the elderly patient. Semin. Respir. Crit. Care Med. 2010, 31, 596-606. [CrossRef] [PubMed]

(C) 2018 by the authors. Licensee MDPI, Basel, Switzerland. This article is an open access article distributed under the terms and conditions of the Creative Commons Attribution (CC BY) license (http:/ / creativecommons.org/licenses/by/4.0/). 